\title{
Chapter 7 \\ Stable isotope analysis of Neolithic to Late Bronze Age populations in the Samara Valley
}

Rick J. Schulting

Michael P Richards

Figure 7.1 Map of sites sampled in Schulting and Richards's isotope study (Chapter 7) and Murphy’s bioarchaeological study (Chapter 8).

\section{Introduction}

The Samara Valley is located in what is today the steppe/forest-steppe zone of the middle Volga region of Russia. The region forms an important communication route between the Central Eurasian steppes and Europe, particularly from the Bronze Age onward, when the domestication of the horse greatly increased the effective mobility of the steppe peoples (Anthony 2007; Anthony and Brown 2000; Outram et al. 2009). The later prehistoric subsistence economy of the region, and the Eurasian steppes in general, is widely thought to have emphasized sheep and cattle pastoralism, with some contribution from cereal agriculture (Khazanov 1994; Koryakova and Epimakhov 2006; Levine 1999; Frachetti 2008), although the degree to which spatial and diachronic variability may have featured is not well understood (Chapter 1). Stable isotope analysis is increasingly being used to investigate the diets of Eurasian steppe populations, providing direct insights into the diets of individuals and the communities to which they belonged (Hollund et al. 2010; Murphy et al. 2013; Privat 2004; Shishlina et al. 2007, 2009, 2012; Shishlina 2008; Svyatko 2009; Svyatko et al. 2013; Ventresca Miller et al. 2014). This chapter presents and discusses stable carbon and nitrogen isotope analyses on the bone collagen of 58 individuals from the Samara Valley and surrounding region, ranging in date from the Neolithic to the Late Bronze Age, with one outlier from the Iron Age. Evidence for domestic 
cattle and sheep appears in the Samara Valley in the Eneolithic, from as early as 4700/4500 BC (Anthony 2007: 182; Anthony and Brown 2011). Cereals are not documented in the region until the Late Bronze Age and even then are rare, although visibility and recovery biases remain possible (Anthony et al. 2005). Specific research questions addressed in this chapter include whether dietary shifts can be detected isotopically between the Neolithic/Eneolithic and Early Bronze Age (EBA), as well as with the beginning of the Late Bronze Age, when a shift toward greater sedentism is attested archaeologically (Chapter 4).

\section{Stable carbon and nitrogen isotopes}

Stable carbon and nitrogen isotope analysis has seen application in many parts of the world over the past few decades, and is now a standard technique used in the investigation of past human and animal diets. Stable carbon $\left(\delta^{13} \mathrm{C}\right)$ isotopes distinguish between terrestrial and marine-based foodwebs, as well as between terrestrial systems based on $\mathrm{C}_{3}$ versus $\mathrm{C}_{4}$ plants, the most economically important of which are maize (Zea mays) and millet (especially Panicum spp. and Secaria spp.) (Schoeninger 1989). Broadly speaking, human consumers reliant on terrestrial $\mathrm{C}_{3}$ systems will have bone collagen $\delta^{13} \mathrm{C}$ values of approximately $-21 \%$, while those reliant on purely $\mathrm{C}_{4}$ systems will have values as high as about -7\%o. Marine systems are intermediate between these two extremes, but can be largely excluded from the present study (Caspian Sea sturgeon were present in the Volga River system [Khodorevskaya et al. 2009], and likely exhibit elevated $\delta^{13} \mathrm{C}$ values, although the isotope ecology of the Caspian is poorly known.) Freshwater aquatic isotopic systems are complex, and may be similar to terrestrial $\mathrm{C}_{3}$ systems, or may be either depleted or enriched in ${ }^{13} \mathrm{C}$ (Dufour et al. 1999; Fry 1991; Katzenberg and Weber 1999). They are best dealt with empirically on a regional or even local basis. There are a number of 
additional sources of variation in plant $\delta^{13} \mathrm{C}$ values, such as a depleting "canopy effect” found in the understory of dense woodlands, and under conditions of water stress (Bonafini et al. 2013; Tieszen 1991). These are comparatively minor relative to the differences between photosynthetic pathways and $\mathrm{C}_{3}$ terrestrial/marine systems noted above, but can contribute significant variation at finer-scale resolutions.

Stable nitrogen $\left(\delta^{15} \mathrm{~N}\right)$ isotopes broadly inform on an organism's trophic level (Schoeninger and DeNiro 1984), although there are other factors involved (Hedges and Reynard 2007). The number of trophic levels is generally limited in the terrestrial ecosystems in which humans generally engage to three: primary producers (plants) and first-order (herbivores) and secondorder (carnivores) consumers. Leaving aside aquatic foods, humans, being omnivorous, will generally consume some balance of plants and herbivores. Herbivore $\delta^{15} \mathrm{~N}$ values can themselves vary widely depending on the values of the plants they consume, but are generally in the range 3 to $7 \%$. Humans are enriched by 3 to 5\% relative to their protein source (they are also enriched by about $1 \%$ in $\delta^{13} \mathrm{C}$ ) (Bocherens and Drucker 2003). Thus, adult humans with values higher than approximately $12 \%$ are likely to have consumed a significant proportion of their protein from higher trophic levels than usually represented by herbivores, such as can be found in freshwater and marine ecosystems (e.g., fish and piscivorous waterfowl). If plants—which usually exhibiting relatively low $\delta^{15} \mathrm{~N}$ values (but see below)—contributed to the diet, the consumption of high-trophic-level foods would need to have been proportionately greater to result in the observed high human values. 
As with $\delta^{13} \mathrm{C}$, however, a number of additional factors affect $\delta^{15} \mathrm{~N}$ values. One of these is the enrichment seen in nursing individuals, since they are effectively raised by one trophic level above their mothers (Schurr 1998). Measurements on human infants, therefore, should be excluded from an analysis of diet at the population level, since they will artificially raise the average and introduce considerable additional variation. This is not a factor in the present study, as only adults were measured. More relevant here is this same effect in domestic animals, as the consumption of young males is a common practice in herding societies, particularly those emphasizing milk production. These animals will be significantly elevated above the adults of the same species that are often used to provide baseline $\delta^{15} \mathrm{~N}$ values. With the single exception of a horse, no faunal isotope values have yet been obtained from the Samara Valley specifically, but comparative data from the wider region are discussed below. Leguminous plants can fix nitrogen directly from the air and so exhibit considerably lower $\delta^{15} \mathrm{~N}$ values than non-nitrogen-fixing plants; however, legumes are not thought to have been a factor in the study area.

Another source of variation involves ${ }^{15} \mathrm{~N}$ enrichment in animals and humans under arid conditions. While the effect itself is well documented, there remains some debate over whether it is the result of changes in soil and plant values due to aridity, to the animal's physiological response to water stress, or to some combination of the two (Ambrose 1991; Gröcke et al. 1997; Heaton 1987; Heaton et al. 1986; Pate and Anson 2008; Sealy et al. 1987; Vanderklift and Ponsard 2003). This is potentially a factor in the present study, since what is today forest-steppe may have been more arid grassland steppe in the Subboreal. Even today, annual rainfall is low in the Samara Valley, averaging around 400 mm, which is classed as semi-arid (Kremenetski et al. 1999). Saltmarshes — which can also be found in non-coastal environments as the result of soil 
salinization—can also exhibit ${ }^{15} \mathrm{~N}$ enrichment (Britton et al. 2008; Heaton 1987; Karamanos et al. 1981; Page 1995; Schwarcz et al. 1999; van Groenigen and Kessel 2002). Finally, the practice of manuring has been shown to increase $\delta^{15} \mathrm{~N}$ values in cereals, which would in turn affect the animals fed either the grain or chaff, or grazing the stubble (Bogaard et al. 2007; Fraser et al. 2011) (although straw is low in protein and would therefore contribute little nitrogen). While a similar but diluted effect can be envisaged for intensively grazed pastures with high stocking rates, this is unlikely to describe the more extensive pastoral systems characteristic of the steppes, although this topic certainly warrants further research (cf. Makarewicz 2014).

Stable isotope measurements on adult human bone collagen reflect an averaged dietary signal over a period of approximately the last decade of an individual's life. There is a bias toward the protein component of the diet in collagen $\delta^{13} \mathrm{C}$ measurements $\left(\delta^{15} \mathrm{~N}\right.$ measurements refer exclusively to protein sources), particularly with moderate to high protein consumption (Ambrose and Norr 1993; Jim et al. 2006). Thus, most plant foods will be underrepresented relative to animal protein, the latter including milk and blood as well as meat. Fish and terrestrial mammals provide similar amounts by weight of high-quality protein.

\section{Materials and methods}

A total of 58 adult human bone (mainly tibia and femur) samples were obtained from Neolithic to Late Bronze Age individuals from a series of sites, centering on the Samara Valley (Figure 7.1). In addition, one horse was sampled, from the Bronze Age site of Potapovka. Cultural attributions and their concomitant chronological spans are based on archaeological data, and, in 23 cases (including the horse), on direct accelerator mass spectrometry (AMS) ${ }^{14} \mathrm{C}$ dating 
(Chapter 2). A small number of samples derive from individuals outside the main study area: Belogor'e on the Volga some $300 \mathrm{~km}$ to the south of the Samara confluence; Ishkinovka on a tributary of the Ural River to the east; and Tanabergin in Khazakhstan. Despite its later date (contemporary with the EBA in the Samara Valley proper), the single sample from Murzikha II is included in the Eneolithic group, as it derives from the forests further to the north, where communities long retained a fishing-hunting-gathering lifestyle (Piezonka et al. 2013; Wood et al. 2013). Age and sex data were determined by Khokhlov (Chapter 6) according to standard osteological criteria. A number of individuals were re-assigned sex on the basis of the results of an ancient DNA study (table 7.1).

Bone collagen was extracted at the Department of Archaeological Science, University of Bradford using the methods outlined in Richards and Hedges (1999) with the addition of an ultrafiltration step (Brown et al. 1988). Isotope measurements were made using a Thermo Finnigan EA coupled to a Delta XP isotope ratio mass spectrometer. $\delta^{13} \mathrm{C}$ values are measured relative to the VPDB (Vienna Pee Dee Belemnite) standard and $\delta^{15} \mathrm{~N}$ values relative to the AIR (Ambient Inhalable Reservoir) standard, and they reported in parts per mil (\%o). Errors on both measurements are approximately \pm 0.2 per mil.

As most of the results are not normally distributed, non-parametric Mann-Whitney U-tests Kruskal-Wallis ANOVA tests are used for statistical analyses of paired and multiple groups, respectively.

\section{Results}


Results are shown in Table 7.1. Most samples demonstrated well-preserved collagen, with C:N values falling between 3.1 and 3.4, with only one marginal result of 3.7 falling just outside the accepted range of 2.9 to 3.6 (DeNiro 1985). The yield for this sample (an adult female from Tanabergin II, Kazakhstan) was also very low (0.1 percent) although lower yields are expected for ultrafiltered collagen. The $\delta^{13} \mathrm{C}$ and $\delta^{15} \mathrm{~N}$ results are entirely in line with other Middle Bronze Age samples; this sample also yielded an acceptable AMS determination (AA47806, $4020 \pm 55$ BP). In any case, this individual derives from well outside the Samara Valley, and so is excluded from further discussion. The single Bronze Age individuals from Belogor'e and Ishkinovka and are also excluded due to their distance from the Samara Valley. Radiocarbon dating placed an individual from Nedezhdinka - initially thought to belong to the Early Bronze Age - in the Iron Age (Beta-392493: $2220 \pm 30 \mathrm{BP}$ ); this sample is also excluded from the analysis.

Table 7.2 Stable carbon and nitrogen isotope averages and standard deviations $(1 \sigma)$ for Neolithic/Eneolithic to Late Bronze Age muman samples from the Samara Valley

\begin{tabular}{|l|c|c:r|}
\hline Period & $\delta^{13} C$ & $\delta^{15} N$ & $n$ \\
\hline Neolithic & $-23.1 \pm 0.1$ & $12.1 \pm 0.1$ & 2 \\
\hline Eneolithic & $-21.0 \pm 1.3$ & $13.7 \pm 1.6$ & 13 \\
\hline Early Bronze Age & $-19.1 \pm 0.6$ & $11.2 \pm 0.9$ & 8 \\
\hline Early/Mid Middle Bronze Age & $-18.9 \pm 0.4$ & $12.0 \pm 1.2$ & 11 \\
\hline Late Middle Bronze Age & $-19.1 \pm 0.6$ & $11.1 \pm 0.3$ & 4 \\
\hline Late Bronze Age & $-19.0 \pm 0.6$ & $11.3 \pm 1.2$ & 16 \\
\hline Samara Bronze Age total & $-19.0 \pm 0.5$ & $11.5 \pm 1.1$ & 39 \\
\hline
\end{tabular}

Table 7.3 Mann-Whitney U-test results for stable carbon and nitrogen isotope averages and standard deviations ( \pm 1SD) assessing locational and/or period differences.

\begin{tabular}{|l|c|c|c|c|c|c|c|}
\hline Period/Site & \multicolumn{1}{|c|}{$\delta^{13} \mathrm{C}$} & \multicolumn{1}{|c|}{$\delta^{15} N$} & \multicolumn{1}{c|}{$n$} & Comparison & iso & $Z$ & $p$ \\
\hline Neolithic & $-23.1 \pm 0.1$ & $12.1 \pm 0.1$ & 2 & Neolithic-Eneolithic & $\delta^{13} \mathrm{C}$ & 1.86 & 0.062 \\
\hline Eneolithic & $-21.0 \pm 1.3$ & $13.7 \pm 1.6$ & 13 & Neolithic-Eneolithic & $\delta^{15} \mathrm{~N}$ & 1.53 & 0.126 \\
\hline Sok River Eneolithic & $-20.6 \pm 1.6$ & $12.4 \pm 1.2$ & 6 & Sok-Volga & $\delta^{13} \mathrm{C}$ & & $\mathrm{n} / \mathrm{s}$ \\
\hline Volga River Eneolithic & $-20.9 \pm 0.7$ & $14.8 \pm 0.7$ & 6 & Sok-Volga & $\delta^{15} \mathrm{~N}$ & 2.88 & 0.004 \\
\hline
\end{tabular}




\begin{tabular}{|l|c|c|c|c|c|c|c|}
\hline Bronze Age (BA) & $-19.0 \pm 0.5$ & $11.5 \pm 1.1$ & 39 & Eneolithic-BA & $\delta^{13} \mathrm{C}$ & 4.43 & 0.000 \\
\hline & & & & Eneolithic-BA & $\delta^{15} \mathrm{~N}$ & 3.73 & 0.000 \\
\hline Late Bronze Age, Spiridonovka & & & & & & \\
\hline Spiridonovka II & $-19.0 \pm 0.5$ & $11.5 \pm 1.2$ & 4 & Spiri II-IV & $\delta^{13} \mathrm{C}$ & & $\mathrm{n} / \mathrm{s}$ \\
\hline Spiridonovka IV & $-18.8 \pm 0.3$ & $10.3 \pm 0.8$ & 5 & Spiri II-IV & $\delta^{15} \mathrm{~N}$ & 1.47 & 0.142 \\
\hline n/s = not significant & & & & & \\
\hline
\end{tabular}

The two Neolithic samples from the Sok River are nearly identical to one another, sharing relatively low $\delta^{13} \mathrm{C}$ and $\delta^{15} \mathrm{~N}$ values relative to individuals attributed to the Eneolithic (Tables 7.2 and 7.3). While it must be seen as tentative given the small sample size and uncertainties over dating, this observation is of some interest in that the Eneolithic sees the introduction of domestic animals. However, dating of human bones in both periods is subject to suspected freshwater reservoir effects (Anthony 2007: 127), making this division a tentative one based on the present evidence. Not in question, despite some overlap in regards to specific individuals, is the clear division observed between the Eneolithic and Bronze Age groups in both isotopes (Figure 7.2). The $\delta^{13} \mathrm{C}$ values are significantly lower (Mann-Whitney U-test, $Z=4.43, p<0.000$ ) in the Eneolithic group, while $\delta^{15} \mathrm{~N}$ values are significantly higher $(Z=3.73, p<0.000)$. This combination of relatively depleted $\delta^{13} \mathrm{C}$ values and, more importantly, elevated $\delta^{15} \mathrm{~N}$ values, may be attributed to the significant consumption of freshwater fish. As discussed further below, there are three probable outliers (retained in the above statistical comparison) in the Eneolithic dataset —all from the site of Lebyazhinka V-with values for both isotopes more similar to those of the Bronze Age group. With these included, there is no correlation between $\delta^{13} \mathrm{C}$ and $\delta^{15} \mathrm{~N}$ for the combined Neolithic/Eneolithic group $\left(r^{2}=0.10, p=0.260\right)$; when they are excluded, however, there is a moderate positive linear correlation $\left(r^{2}=0.38, p=0.034\right)$. The removal of the single result from Murzikha II, arguably another outlier (and from the northern forest, a different 
ecological zone), improves the correlation in the Neolithic/Eneolithic group significantly $\left(r^{2}=\right.$ 0.79, $p<0.000)$. A similar trend is seen in the combined Bronze Age group $\left(r^{2}=0.32, p<\right.$ 0.000), but on a substantially different trajectory with differing beginning and end points.

Figure 7.2 Bivariate plot of $\delta^{13} \mathrm{C}$ and $\delta^{15} \mathrm{~N}$ values for pooled Neolithic/Eneolithic and Bronze Age humans from the Samara Valley.

If fish are the main source of protein responsible for this pattern in both cases, they must have been at least slightly elevated in $\delta^{13} \mathrm{C}$ relative to other sources of protein, and significantly so in $\delta^{15} \mathrm{~N}$. The protein sources in the Neolithic/Eneolithic must have been considerably depleted in ${ }^{13} \mathrm{C}$ relative to later periods. This could be the result of taking game from $\mathrm{C}_{3}$ habitats (forests) rather than the steppe or that avoided $\mathrm{C}_{4}$ plants if they did graze on the latter. While no fish values are available from the Samara Valley, a single pike (Esox lucius) sample from a Bronze Age Caspian site provides values of $-16.5 \%$ and $15.0 \%$ for $\delta^{13} \mathrm{C}$ and $\delta^{15} \mathrm{~N}$ respectively (Shishlina et al. 2007). Although the $\delta^{15} \mathrm{~N}$ value would be consistent with the observed Neolithic/Eneolithic human results, the $\delta^{13} \mathrm{C}$ value is too high. As noted above, however, freshwater ecosystems can demonstrate considerable isotopic variability, and values may have differed along the waterways of the middle Volga region. In fact, the Caspian pike itself seems to be something of an outlier (perhaps reflecting time spent feeding in the Caspian Sea), with other fish $\delta^{13} \mathrm{C}$ values from Central Eurasia being significantly lower relative to terrestrial fauna (Privat 2004). This presents something of a conundrum in terms of the significant positive correlation observed between $\delta^{13} \mathrm{C}$ and $\delta^{15} \mathrm{~N}$ values for the Neolithic/Eneolithic (with four outliers excluded) and Bronze Age periods. Given the different trajectories noted above, isotopically distinct foods must be responsible for this pattern in each period. The problem here 
is the lack of floral and faunal data for the region, particularly the full range of fish/waterfowl. As discussed further below, another possible explanation for the Bronze Age pattern in particular relates to the isotope ecology of the terrestrial flora and fauna of the Samara Valley.

Figure 7.3 Bivariate plot of $\delta^{13} \mathrm{C}$ and $\delta^{15} \mathrm{~N}$ values humans from the Samara Valley by period.

No significant isotopic differences are apparent between the Early, Middle and Late Bronze Age (Kruskal-Wallis ANOVA, $\delta^{13} \mathrm{C}: p=0.89 ; \delta^{15} \mathrm{~N}: p=0.25$; Table 7.2; Figure 7.3), nor is there any difference between the earlier and later phases of the MBA, a transition marked by significant developments in many aspects of society (Chapters 1 and 4). Nor are any significant changes seen in the LBA compared to earlier phases. While $\delta^{15} \mathrm{~N}$ values are considerably lower than for the preceding Eneolithic period (ca. 11.5\%o vs. ca. 13.7\%), they remain high in absolute terms (as compared to most inland Neolithic/Bronze Age European values (Schulting 2011)), and so freshwater fish may have still featured in the diet, although considerably less so than in the Eneolithic. Nor is there any clear indication of the uptake of millet agriculture in the Samara data - as a $\mathrm{C}_{4}$ plant, the consumption of millet in any quantity would have a marked impact of human $\delta^{13} \mathrm{C}$ values, and would be clearly detectable if present (cf. Murphy et al. 2013; Privat 2004; Svyatko 2009; Svyatko et al. 2013). While it could be argued that the $\delta^{13} \mathrm{C}$ values are in fact slightly elevated, the positive correlation with $\delta^{15} \mathrm{~N}$ for the Bronze Age group makes it unlikely that millet consumption is the explanation for this. Steppe grasslands typically include various wild $\mathrm{C}_{4}$ plants (Pyankov et al. 2000; Wang 2003, 2004, 2005), and so domestic and wild grazing animals could introduce elevated $\delta^{13} \mathrm{C}$ values into the human foodchain. 
While faunal isotope values from the Samara Valley itself are at present limited to a single horse, Eneolithic to Iron Age faunal data are available from the surrounding area, including the northwest Caspian region (Shishlina 2008; Shishlina et al. 2007, 2009), the Ukraine (O’Connell et al. 2003; Privat 2004), the Don River region (Iacumin et al. 2004), the North Caucasus (Hollund et al. 2010), the southern Urals/western Siberia (Privat 2004) and, more distantly, the Altai region (Privat 2004). Unfortunately, none of these locations could be said to be near the present study area; however, while some interesting regional variation is subsumed in the averages shown in Table 7.4, the values overall are quite consistent within each species/group, which does suggest a certain degree of confidence in their general validity and applicability to the Samara Valley. One important trend in terms of the interpretation of the human values is that ovicaprids (mainly sheep) are significantly elevated (at the 0.05 level) in both $\delta^{13} \mathrm{C}$ and $\delta^{15} \mathrm{~N}$ compared to cattle, and both are elevated compared to horse. While there is some variation, sheep are often significantly higher in $\delta^{13} \mathrm{C}$ relative to the expectation of around $-22 \%$ for herbivores in a purely $\mathrm{C}_{3}$ ecosystem (e.g., the averages observed for horse and red/roe deer in Table 7.4). Measurements on 28 Bronze Age sheep from the northwest Caspian, for example, average $-18.1 \pm 2.1 \%$ (Shishlina 2008; Shishlina et al. 2007, 2009), while 15 sheep from the North Caucasus average $-18.1 \pm 1.6 \%$ (Hollund et al. 2010). Within Privat’s (2004:Appendix 1) larger dataset, nine sheep from sites of the Middle Bronze Age Sintashta culture average $-18.1 \pm$ 0.7\%o, and five sheep from the Early Bronze Age component at Abganerovo on the Don River average $-18.3 \pm 1.2 \%$ o (Iacumin et al. 2004). This suggests that sheep and horse in particular were grazing on different parts of the landscape, favoring different plants within the same landscape, and/or were being managed differently (e.g., through foddering). 
Table 7.4 Stable carbon and nitrogen isotope averages and standard deviations ( $\pm 1 \mathrm{SD}$ ) for Neolithic/Eneolithic to Middle Bronze Age fauna from Central Eurasia. Only Privat (2004) specifies that only adult animals were analysed. Sources: this study, Hollund et al. 2010, Iacumin et al. 2004; O’Connell et al. 2003; Privat 2004; Shishlina 2008; Shishlina et al. 2007, 2009.

\begin{tabular}{|l|l|l|r|r|r|}
\hline Region & Period & Species & $\delta^{13} \mathrm{C}$ & $\delta^{15}$ & $n$ \\
\hline Samara & MBA & Horse & -20.6 & 3.8 & 1 \\
\hline Northwest Caspian & Eneolithic-MBA & Sheep & $-18.1 \pm 2.1$ & $9.9 \pm 2.2$ & 28 \\
\hline Northwest Caspian & EBA/MBA & Cattle & $-18.6 \pm 1.7$ & $9.3 \pm 2.1$ & 4 \\
\hline Northwest Caspian & EBA/MBA & Horse & $-20.6 \pm 0.6$ & $5.5 \pm 0.8$ & 3 \\
\hline Northwest Caspian & EBA/MBA & Pike & -16.5 & 15.0 & 1 \\
\hline North Caucasus & Eneolithic, EBA & Sheep/goat & $-18.1 \pm 1.6$ & $8.3 \pm 2.2$ & 15 \\
\hline North Caucasus & Eneolithic, EBA & Cattle & $-19.7 \pm 0.7$ & $7.4 \pm 1.0$ & 15 \\
\hline North Caucasus & Eneolithic, EBA & Horse & $-20.0 \pm 0.5$ & $8.2 \pm 1.8$ & 3 \\
\hline North Caucasus & Eneolithic, EBA & Pig & $-19.3 \pm 0.3$ & $7.6 \pm 2.6$ & 2 \\
\hline North Caucasus & Eneolithic, EBA & Dog & $-19.4 \pm 0.1$ & $9.6 \pm 0.5$ & 2 \\
\hline Abganerovo & EBA & Cattle & $-19.5 \pm 0.4$ & $6.9 \pm 1.8$ & 2 \\
\hline Abganerovo & EBA & Sheep & $-18.3 \pm 1.3$ & $9.2 \pm 1.9$ & 5 \\
\hline Ukraine and Kazakhstan & Neolithic to EBA & Horse & $-20.7 \pm 0.7$ & $3.9 \pm 1.3$ & 15 \\
\hline Ukraine & EBA & Cattle & $-19.6 \pm 0.8$ & $5.7 \pm 0.1$ & 2 \\
\hline Central Eurasia & Eneolithic to IA & Dog & $-19.8 \pm 1.8$ & $10.9 \pm 1.5$ & 16 \\
\hline Central Eurasia & Eneolithic to IA & Cattle & $-19.9 \pm 0.7$ & $6.6 \pm 1.1$ & 88 \\
\hline Central Eurasia & Eneolithic to IA & Sheep/goat & $-19.4 \pm 0.9$ & $7.2 \pm 1.2$ & 85 \\
\hline Central Eurasia & Eneolithic to IA & Horse & $-20.5 \pm 0.5$ & $5.0 \pm 1.2$ & 63 \\
\hline Central Eurasia & Eneolithic to IA & Red/roe deer & $-21.5 \pm 2.2$ & $6.4 \pm 1.5$ & 19 \\
\hline Central Eurasia & Eneolithic to IA & Pig & $-20.8 \pm 0.6$ & $7.7 \pm 1.3$ & 25 \\
\hline Central Eurasia & Eneolithic to IA & Fish, various & $-22.8 \pm 1.6$ & $10.6 \pm 1.7$ & 29 \\
\hline
\end{tabular}

Another possibility involves physiological differences between species, as these demonstrate marked differences in $\delta^{15} \mathrm{~N}$ results, with significantly decreasing averages from sheep to cattle to horse in the combined dataset. Nearly one-third of the sheep values reported by Privat (2004) are above $8 \%$, and no young animals were included in her study (so that this cannot reflect a nursing signal). These results are unusually elevated for herbivores; although to a lesser extent, many of the cattle values are also high. Values for horse are generally low in all regions for which data are available, including the single measurement from the Samara Valley itself (Table 7.4). These inter-species differences may be due to differences in grazing/browsing preferences (and the associated $\delta^{15} \mathrm{~N}$ values of the plants), as noted above, and/or to physiological differences. Regarding the latter, it is worth noting that sheep and cattle are ruminants, in which ingested 
plant matter is broken down and fermented by gut organisms, with some of the by-products being digested by the animal: isotopic fractionation can potentially occur at each of these steps. By contrast, the hindgut fermentation found in horses, while analogous in function to the rumen, does not permit the absorptions of proteins (Alexander 2009). Therefore, ruminants and nonruminants should be considered separately in isotopic studies.

If these faunal data can be applied to the Samara Valley, then the combination of elevated human $\delta^{13} \mathrm{C}$ and $\delta^{15} \mathrm{~N}$ values is more consistent with sheep and cattle being the major mammalian sources of protein, rather than horse or deer. Their low $\delta^{15} \mathrm{~N}$ values mean that horse in particular was unlikely to have played an important role in human diet. This raises an interesting issue for the Eneolithic group, given that horse comprises 40 to 60 percent of large mammal remains on many steppe sites of this period (Anthony and Brown 2000). It is difficult to reconcile the regular consumption of horse with the high $\delta^{15} \mathrm{~N}$ values found in humans, unless high-trophic-level fish featured very strongly. However, the large mammalian fauna at some Eneolithic sites, such as Khvalysnk, is dominated by sheep/goat (61 percent) and cattle (27 percent) with horse making a relatively small contribution (13 percent) (Anthony and Brown 2011: Fig. 1). There is less of a discrepancy with the Bronze Age, when faunal assemblages are dominated by sheep and cattle (Chapter 15, this volume), although two Late Bronze Age Srubnaya sites in the valley, Moeknoe Ozero I and Suskanskoe I, are dominated by cattle but with horse being as abundant as sheep (Morales and Antipina 2003:Table 22.2).

No differences are apparent between the sexes (Figure 7.4), although the female sample size is limited to only two or three individuals for each period, with the exception of the Late Bronze 
Age, comprising nine females and seven males exhibiting similar average $\delta^{13} \mathrm{C}$ and $\delta^{15} \mathrm{~N}$ values. This should be a sufficient sample size to detect any consistent differences should they exist, and their absence suggests that male and female diets were not isotopically distinct. The same result is obtained when the Bronze Age sample as a whole is considered. As only adults were sampled, it is not possible to consider age-based differences in diet.

Figure 7.4 Bivariate plot of $\delta^{13} \mathrm{C}$ and $\delta^{15} \mathrm{~N}$ values for Neolithic and Bronze Age males and females from the Samara Valley.

The large number of sites involved makes it difficult to investigate meaningful inter-site differences, but there are indications that this might be a factor. The clearest example relates to the small number of Eneolithic individuals from the Sok and Volga Rivers, from the sites of Lebyazhinka V and Khvalysnk II, respectively, with the latter exhibiting significantly higher $\delta^{15} \mathrm{~N}$ values (Mann-Whitney U-test, $p=0.004$ )—indeed, the ranges for the two groups are completely non-overlapping (Tables 7.1, 7.3). This difference may relate to the consumption of different dietary items and/or to differing isotope ecologies in the two rivers. Confusing the interpretation somewhat is the fact that the lower $\delta^{13} \mathrm{C}$ values from the tributary Sok River are associated with lower, rather than higher, $\delta^{15} \mathrm{~N}$ values: if fish were depleted in ${ }^{13} \mathrm{C}$, then it would be expected that lower values were associated with enriched ${ }^{15} \mathrm{~N}$. Nevertheless, the best available hypothesis available at present is that freshwater fish are largely responsible for the overall high $\delta^{15} \mathrm{~N}$ values seen in both groups. The observed difference, then, may relate to differing proportions and/or types of fish in the diet or to baseline differences in the fish themselves. Interestingly, while they do differ significantly in both isotopes, the two Neolithic individuals 
from the Sok River are more similar to the Eneolithic group from the same area than they are to the Volga River group.

There are three Eneolithic individuals from the site of Lebyazhinka $V$ with values much more in keeping those seen in the Bronze Age. One has been directly ${ }^{14} \mathrm{C}$-dated (Table 2.1), so this individual at least is not a case of mistaken chronological attribution; the other two could possibly have been incorrectly attributed, but this analysis will proceed on the assumption that their Eneolithic affiliation as provided by our Samara colleagues is correct. ${ }^{1}$ Since their $\delta^{15} \mathrm{~N}$ values are lower, suggesting less consumption of freshwater fish, the dates are unlikely to be too old due to a reservoir effect. Three other individuals from Lebyazhinka $\mathrm{V}$-all deriving from the same multiple burial, along with one of the three aforementioned individuals—have lower $\delta^{13} \mathrm{C}$ values and higher $\delta^{15} \mathrm{~N}$ values, more typical of the Eneolithic data as a whole. (In terms of the comparison made above between Lebyazhinka V and Khvalysnk, it should be noted that even when the three individuals with 'Bronze Age diets' are excluded, the difference in $\delta^{15} \mathrm{~N}$ between the sites remains significant [Mann-Whitney U-test, $p=0.02]$.) Individuals buried at Lebyazhinka V seem to have had very different diets, likely relating to varying consumption of freshwater fish. Such a strong dietary difference is surprising for this period, if, as assumed here, all the individuals are more or less contemporaneous, given the sharing ethic that usually predominates among hunter-gatherers (Kelly 2013).

\footnotetext{
${ }^{1}$ Editor's note: The information on grave and site contexts provided when all of the samples in this report were initially collected in the Samara laboratory in 1999 later proved to contain transcription errors, when compared to the laboratory catalogue. Some uncertainties about grave numbers were cleared up by obtaining direct ${ }^{14} \mathrm{C}$ dates, most of which confirmed the chronological assignments in the catalogue. Here, one collective grave and one individual grave were confirmed as Eneolithic by direct ${ }^{14} \mathrm{C}$ dates. The other two individual graves nearby, which are more anomalous isotopically than the dated individual grave, are nevertheless assumed to be correctly assigned to the Eneolithic by Samara archaeologists.
} 
There is also an intriguing hint of a difference in $\delta^{15} \mathrm{~N}$ between individuals from the Late Bronze Age Srubnaya sites of Spiridonovka II and Spiridonovka IV, on the Samara River, although given the low numbers involved this does not attain statistical significance $(p=0.142$; Table 7.3). Because the sites are found very close together, presumably the same foods were available in the general environment of each, and so cultural choice and/or access to different technologies can be envisaged as a possibility.

\section{Discussion}

The clearest trend to emerge from the Samara Valley stable isotope data is the marked difference between the Eneolithic and the Bronze Age. This is interpreted as indicating a substantially greater contribution of freshwater fish and no detectable $\mathrm{C}_{4}$ input in the diet of most individuals in the earlier population, in contrast to a lower contribution of fish and a greater influence of wild $\mathrm{C}_{4}$ plants, primarily via grazing stock, in the later population. The timing of this shift can only be viewed in broad terms at this stage, pending a program of further AMS ${ }^{14} \mathrm{C}$ dating. The earliest Bronze Age individual comes from the site of Lopatino I, dating to 3300 to 2920 cal BC (68 percent confidence, AA47804), with stable isotope values already typical of the Bronze Age group as a whole. The latest individuals attributed to the Eneolithic lack direct radiocarbon dates, but are placed in the period around 4000 to 3500 cal BC, with stable isotope values typical of that period as a whole. Thus, there may be an intervening period of up to a millennium between the two groups, so that it is not possible to address the speed with which the dietary change occurred. The shift could have involved a greater commitment to a specialized pastoral economy, with much reduced use of wild resources, particularly fish. This is not surprising given that the Early Bronze Age in the western steppes is thought to have opened with a shift to a much more 
mobile form of pastoralism practiced by the Yamnaya or Pit-Grave culture. The use of the steppe grasslands would have played an increasingly important role in the pastoral component of the economy (Shishlina 2001). Interestingly, there is no suggestion of any dietary change across the later phases of the Bronze Age, including the archaeologically observed shift to greater sedentism at the end of the Middle Bronze Age (Potapovka) and the beginning of the Late Bronze Age, which was the principal focus of the Samara Valley Project. This must have involved significant changes in the subsistence economy, although of course these would not necessarily be detectable isotopically. They may, for example, have more to do with animal management practices than with any change in the foods eaten. A similar lack of isotopic evidence for dietary change across this period has been reported in a recent study in northern Kazakhstan (Ventresca Miller et al. 2014).

A more precise interpretation of Samaran Bronze Age human diets will require the analysis of associated floral and faunal samples, ideally including contemporary fish remains. In the absence of these, comparisons must be drawn more widely, although this is problematic given variation, first, in the natural environment (the ratio of $\mathrm{C}_{3}: \mathrm{C}_{4}$ plants, aridity, nitrogen balance, etc.), and, second, in animal management practices (e.g., stocking rates, foddering). With this caveat firmly in place, it can be noted that sheep across the Central Eurasian steppes do show enriched $\delta^{15} \mathrm{~N}$ values (averaging 7-10\%) that, if the comparison is warranted, would go some way to accounting for the Samara Valley Bronze Age data. The latter's average $\square \mathrm{f} \square 11.5 \pm 1.1 \%$ is elevated by approximately $2 \%$ compared to other human averages commonly seen in mixed farming groups across prehistoric Europe (Richards 2000; Schulting 2011). It is slightly higher than the average of $10.9 \pm 1.7 \%$ for Neolithic individuals in the Dnieper Rapids region of the 
Ukraine, who are thought to have incorporated substantial amounts of fish in their diets (Lillie and Jacobs 2006; Lillie and Richards 2000). Other inland human groups inferred to have had an important dietary contribution from fish include those of the Mesolithic and Early Neolithic Iron Gates (averaging around 14\%o) to the west and those of the Mesolithic to Early Bronze Age Lake Baikal region to the east (showing greater spatial and temporal variability, with averages ranging 10-14\%) (Bonsall et al. 1997; Borić et al. 2004; Katzenberg and Weber 1999; Katzenberg et al. 2009, 2010). Finally, the Late Bronze Age site of Chicha in the Altai region also exhibits high human values (14.5 $\pm 1.0 \%$ ) that have been attributed to fish consumption (Privat 2004).

The above comparisons, however, are rather distant from the Samara Valley both spatially and temporally. As has already been intimated with the fauna, more appropriate comparisons are available, from the Early Bronze Age cultures of the Caspian, spanning the period around 3300 to 2000 cal BC (or 2600-2000 cal BC if a reservoir effect is taken into account) (Shishlina et al. 2007; van der Plicht et al. 2007), and from the Middle Bronze Age Sintashta culture of the southern Urals (Privat 2004). These groups, then, are broadly contemporary with those of the Bronze Age Samara Valley, and occupy a not too dissimilar steppe environment (albeit still distant, with the Caspian lying some $500 \mathrm{~km}$ to the south, and the Sintashta sites some $500 \mathrm{~km}$ to the east). The argument that a reservoir effect needs to be taken into account in the Caspian study derives from the paired ${ }^{14} \mathrm{C}$ dating of human/herbivore and human/plant samples from the same graves, in association with elevated human $\delta^{15} \mathrm{~N}$ values that are difficult to explain without inferring the consumption of considerable quantities of fish (van der Plicht et al. 2007). A comparison of the Caspian and Samaran datasets, however, clearly shows that the $\delta^{15} \mathrm{~N}$ values for the former are on average substantially higher $(15.2 \pm 1.8 \%$ ) than those for both the 
Eneolithic and Bronze Age of the Samara Valley (Table 7.5, Figure 7.5). The data from Bronze Age sites in the North Caucasus, the southern Urals and western Siberia, on the other hand, are very similar to those for the Samara Valley (Table 7.5). In relation to the terrestrial fauna from the same region, the human values are not markedly elevated above what might be expected, particularly if sheep are assumed to have provided the major source of protein (cf. Privat 2004:74).

Table 7.5 Stable carbon and nitrogen isotope averages and standard deviations ( \pm 1SD) for Bronze Age adolescent/adult humans from selected regions of Central Eurasia.

\begin{tabular}{|c|c|c|c|c|c|}
\hline Region & Period & $\delta^{13} C$ & $\delta^{15} N$ & $n$ & Source \\
\hline Samara Valley & EBA to LBA & $-19.0 \pm 0.5$ & $11.5 \pm 1.1$ & 47 & This study \\
\hline Ukraine & EBA to LBA & $-18.9 \pm 1.2$ & $12.4 \pm 0.9$ & 29 & Privat 2004 \\
\hline Northwest Caspian & EBA to MBA & $-17.7 \pm 1.0$ & $14.9 \pm 1.7$ & 74 & Shishlina 2008; Shishlina et al. 2007, 2009 \\
\hline North Caucasus & EBA & $-18.8 \pm 0.9$ & $12.0 \pm 1.4$ & 46 & Hollund et al. 2010 \\
\hline $\begin{array}{l}\text { Abganerovo, Don } \\
\text { River }\end{array}$ & EBA & $-17.7 \pm 0.9$ & $14.1 \pm 1.7$ & 7 & Iacumin et al. 2004 \\
\hline $\begin{array}{l}\text { Southern Urals/western } \\
\text { Siberia steppe }\end{array}$ & MBA to LBA & $-18.9 \pm 0.5$ & $11.1 \pm 0.8$ & 37 & Privat 2004 \\
\hline $\begin{array}{l}\text { Southern Urals/western } \\
\text { Siberia forest-steppe }\end{array}$ & MBA & $-18.1 \pm 0.5$ & $12.8 \pm 1.1$ & 19 & Privat 2004 \\
\hline Chicha, Altai & LBA & $-19.5 \pm 0.6$ & $14.5 \pm 1.0$ & 11 & Privat 2004 \\
\hline
\end{tabular}

Figure 7.5 Bivariate plot of $\delta^{13} \mathrm{C}$ and $\delta^{15} \mathrm{~N}$ values for humans and fauna from selected Central Eurasian

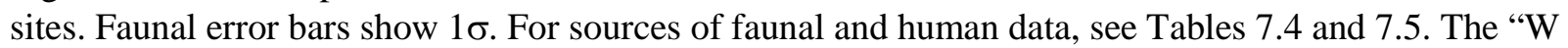
Volga Eneolithic" measurements derive from the site of Khalynsk II (Shishlina et al. 2009), which also features in the Samara data set; with the exception of one outlier low in $\delta^{15} \mathrm{~N}$, there is good correspondence between the two studies.

Thus, while fishing may have played some role in the Samaran Bronze Age, it is unlikely on present evidence to have been a major part of the subsistence economy. This, incidentally, suggests that the radiocarbon dated human remains in the Samara Valley are probably not subject to a large reservoir effect, at least for the Bronze Age, although this would certainly merit testing. No reservoir effect was found in a recent study using paired human/faunal dates from the 
Early Bronze Age of the North Caucasus (Hollund et al. 2010). Further east, no clear relationship was found between $\delta^{15} \mathrm{~N}$ values and AMS determinations on Bronze Age humans from the Minusinsk Basin, suggesting, although admittedly not proving, the lack of a substantial reservoir effect there (Svyatko et al. 2009). That a significant reservoir effect has been demonstrated for the Catacomb cultures of the northwest Caspian region (Shishlina et al. 2007, 2009; van der Plicht et al. 2007) points to regional variability in the use of fish and/or in their reservoir effects (see also Higham et al. 2010). Estimating the potential contribution of freshwater aquatic resources from $\delta^{13} \mathrm{C}$ values is problematic, as these can vary significantly between different drainages (Dufour et al. 1999; Katzenberg and Weber 1999). Thus, for example, the elevated value of $-16.5 \%$ seen for the single pike from the Caspian study may not be applicable to the Samara Valley.

A number of recent isotopic studies have drawn attention to the apparent importance of fish in the diets of Central Eurasian steppe populations, with estimates ranging as high as 50 percent of protein consumption (O’Connell et al. 2003; Privat 2004; Privat et al. 2005; Shishlina et al. 2007; 2009; Svyatko et al. 2013; van der Plicht et al. 2007). This is only partly supported in the present study, primarily for the Neolithic/Eneolithic period, in keeping with the results of other isotopic studies on sites in the Upper Volga forest zone to the north (Piezonka et al. 2013; Wood et al. 2013). For the Bronze Age, other explanations should be considered. First among these is that the high $\delta^{15} \mathrm{~N}$ values seen for sheep and cattle suggest that the range of faunal variability may be underestimated, particularly as the bulk of these data derive from adult animals, and young animals would exhibit even more enriched values (some of which are likely represented in the data, although this is not specified). Furthermore, grazing of animals in wetland pastures- 
inferred from the locations of many Samara Valley settlements—might also be expected to result in elevated $\delta^{15} \mathrm{~N}$ values (Britton et al. 2008), although this remains to be tested specifically for this region. Highly variable $\delta^{15} \mathrm{~N}$ values have been reported for $\mathrm{C}_{3}$ reed matting found in Caspian kurgans, with a number of results $>10 \%$, with the highest being 21\%o (Shishlina et al. 2012: Table 5) - well above any of the human or faunal values that have so far been found in the same region. As noted by Shishlina et al. (2012:184), winter foddering with even a small amount of such material could certainly introduce elevated ${ }^{15} \mathrm{~N}$ into the human food chain.

Particularly noteworthy is the moderate positive correlation between $\delta^{13} \mathrm{C}$ and $\delta^{15} \mathrm{~N}$ values seen in Central Eurasian ovicaprids $\left(r^{2}=0.34 ; d f=84, t=6.5, p<0.000\right.$ ), with an even stronger correlation seen in humans $\left(r^{2}=0.68 ; d f=55, t=10.8, p<0.000\right)$ (data from Privat 2004). Hollund et al. (2010) report comparable findings for Early Bronze Age ovicaprids $\left(r^{2}=0.31\right.$ ) and humans $\left(r^{2}=0.65\right)$ in the North Caucasus. A moderate positive correlation $\left(r^{2}=0.32\right)$ was also noted above for Bronze Age humans from the Samara Valley. More widely, a positive correlation between $\delta^{13} \mathrm{C}$ and $\delta^{15} \mathrm{~N}$ for the Bronze Age across the overall western steppe region can be clearly seen ( $\mathrm{n}=264, r^{2}=0.38$, increasing to $r^{2}=0.51$ when four outliers are excluded, $p$ $<0.000$; Figure 7.5). The explanation for this most likely relates to environmental factors (Hollund et al. 2010; Shishlina et al. 2009; 2012). Specifically, as was noted above, increasing aridity results in higher $\delta^{15} \mathrm{~N}$ values in plants and animals. In addition, aridity favors the proportion of $\mathrm{C}_{4}$ plants in the environment and leads to enriched ${ }^{13} \mathrm{C}$ values in $\mathrm{C}_{3}$ plants (Castañeda et al. 2009; Pyankov et al. 2000; Wang 2004, 2005; Winter 1981), both of which would elevate the $\delta^{13} \mathrm{C}$ values of grazing herbivores. In this regard, it should be noted that the period around 2500 to $1700 \mathrm{BC}$ in the study area has been characterized as particularly arid 
(Kremenetski et al. 1999; Chapter 5, this volume). Finally, $\delta^{15} \mathrm{~N}$ values are often elevated in wetland and saltmarsh habitats, which may be a factor locally (cf. Shishlina et al. 2012). If it is assumed that sheep milk and meat contributed the majority of the protein in Bronze Age human diets in the Samara Valley, and applying a 4\%o trophic level shift in $\delta^{15} \mathrm{~N}$, there may be no need to invoke any significant degree of fish consumption in order to account both for the $\delta^{15} \mathrm{~N}$ values in Bronze Age humans and for the correlation between $\delta^{13} \mathrm{C}$ and $\delta^{15} \mathrm{~N}$. It might be mentioned here that dogs, being omnivorous, also typically exhibit elevated $\delta^{15} \mathrm{~N}$ values and, if they were regularly consumed, would affect human values (Table 7.4; Figure 7.5). This recalls the (so far) unique finding of the butchered remains of many dogs at the Srubnaya settlement of Krasnosamarskoe IV, although this appears to have taken place in a ritual feasting context and may not have been a regular occurrence (Anthony et al. 2005; Chapters 14 and 16, this volume). Of course, none of this is to say that fish were not consumed in the Bronze Age Samara Valley but rather that their contribution to the overall diet may be exaggerated if these other potential sources are not considered. At the least, as noted by Privat (2004:83), the importance of fish is likely to have varied through space and time.

The isotopic data from the Samara Valley provide no evidence for the presence of millet, or, if it was present, for its consumption in any significant quantity. The Central Asian “gap” between the early (pre-5000 cal BC) presence of millet both to the west and to the east (Hunt et al. 2008; Zohary and Hopf 2000) has been recently called into question by the direct AMS dating of 10 examples of millet putatively from early contexts in Europe, all of which proved to date to postdate ca. 1500 cal BC, though it is acknowledged that records from the mid-fourth millennium onwards are probably reliable (Motuzaite-Matuzeviciute et al. 2013). Millet does not appear in 
Central Asia until the mid-second millennium, so that something of a gap may still remain, though a reduced one. Carbonized broomcorn millet (Panicum miliaceum) recently discovered at Begash Ia in eastern Kazakhstan has been directly dated to $3840 \pm 40$ BP (Beta-266458: 24622154 cal BC at 95.4 percent confidence) (Frachetti et al. 2010). While a single fragmentary wheat grain had to be added to the sample of seven millet grain fragments giving this result in order to achieve the then required weight for AMS ${ }^{14} \mathrm{C}$ analysis, other dates on charcoal from the same archaeological context produced comparable results, and so it should be reliable (Frachetti et al. 2010:1003-1004). Millet dating to the late third/early second millennium BC has also been claimed for two sites in the "Country of Towns"-Arkaim and Alandskoe-(Gaiduchenko 2002) somewhat nearer the Samara Valley, although Frachetti et al. (2010:1005) express caution in the acceptance of this evidence without further morphological information and direct dating.

The nearest sites to Samara with claimed early evidence of millet, in both cases by the fifth millennium, are in the Ukraine to the west and in Georgia to the south (Hunt et al. 2008; Séfériadès 2000), though these can now be called into question in the absence of direct dating of the grains themselves (Motuzaite-Matuzeviciute et al. 2013). Despite the wide date ranges associated with some of the human remains in the present study, attributed only to a broad cultural-chronological phase, it seems likely that none fall later than ca. 1500 BC, which would be consistent with those individuals that have been directly radiocarbon dated. In addition, there is the absence of any cultivated cereals of any kind in Eneolithic and Bronze Age sites in the Samara Valley despite a program of sampling and flotation (Chapter 5, this volume; Anthony et al. 2005); indeed, this applies to the Pokrovskaya Srubnaya culture area as a whole (Otroshchenko 2003). The dental palaeopathological evidence also supports the scarcity of 
sugars and carbohydrates in the diet, with very low caries prevalence, although the etiology of caries is complex, and there are other factors to consider (Chapter 8). Interestingly, the wild plant seeds identified in the Samara Valley Project include the genus Amaranthus (Chapter 12), which is composed of $\mathrm{C}_{4}$ species (Willis 1973). Their consumption could have made some direct contribution to the elevated human $\delta^{13} \mathrm{C}$ values.

The general absence of sex-based differences is mirrored in other studies of steppe populations (Svyatko et al. 2013), although it should be kept in mind that this does not mean that no such distinctions were present but only that if they did exist, they did not involve foods that differed isotopically. The simple fact that the burial population contains so many more males than females for all periods in the Samara Valley, with the exception of the Late Bronze Age, would suggest the existence of some social distinctions based on gender (Chapter 8). Indeed, data from the Bronze Age Catacomb culture of the northwest Caspian region may offer an exception, with males showing slightly more depleted $\delta^{13} \mathrm{C}$ values than females ( $-17.8 \pm 1.0 \%$ vs. $-17.2 \pm 0.8 \%$; $d f=54, t=2.55, p=0.01$ ) (data from Shishlina 2008; Shishlina et al. 2007). As only adults were analyzed in the present study, it is not possible to investigate subadult-adult differences, and the sample size is too small to compare adults in different age classes, for which any dietary distinctions would be expected to be very minor. Limited data are available on archaeological associations for the Samara Valley sample analyzed here, and possible dietary differences linked to socioeconomic status have not yet been investigated.

\section{Conclusions}


The stable isotope data reported here for Neolithic to Late Bronze Age populations from the Samara Valley contribute toward our expanding knowledge of the subsistence adaptations of prehistoric Central Eurasian steppe populations. What isotopic differences are found in the small Neolithic/Eneolithic group appear to relate first and foremost to site location, although considerable variability was also noted within the cemetery at Lebyazhinka V. A much clearer isotopic distinction is seen between the Neolithic/Eneolithic and Bronze Age periods, apparently involving a substantial decrease in—although not necessarily an abandonment of—-the consumption of freshwater fish (and perhaps other freshwater aquatic resources such as migratory birds). There is no evidence for any (isotopically visible) dietary change between the Middle and Late Bronze Ages, a key transition period being investigated by the Samara Valley Project. Nor is there any evidence for the uptake of millet agriculture in the early and middle stages of the Late Bronze Age represented here.

Given the small sample sizes available for any single site, consideration of the possibility of finer-scale spatial variability is limited; nevertheless, there is evidence for the existence of isotopic differences between sites along the Sok and Volga Rivers in the Neoliothic/Eneolithic period and perhaps between two Samara River sites, Spiridonovka II and IV, in the Late Bronze Age. The underlying bases for both temporal and spatial distinctions remain unclear and require further investigation, specifically the analysis of additional humans and, equally, of a range of associated faunal remains. Possible explanations include climate change (Hollund et al. 2010; Kremenetski et al. 1999; Shishlina et al. 2009; 2012) and varying animal management practices (stocking rates, shifts in the time spent on different pastures, foddering, etc.) as well as actual differences in the foods consumed. 
Subsistence adaptations of the Bronze and Iron Age steppe peoples are of considerable interest, given the dynamic expansions of various nomadic groups at this time, and their far-reaching influences. Equally, there are opposing, or complementary, processes of sedentarization—with or possibly without the concomitant uptake of agriculture-in some areas at this time. In the midst of these debates, a number of recent studies have suggested the previously unexpected importance of freshwater fish in steppe diets. The data presented here provide limited support for the latter position, most convincingly for the Eneolithic period, and less so for the Bronze Age that has been a focus of most other Central Eurasian studies. This is seen most clearly in a comparison of the Bronze Age $\delta^{15} \mathrm{~N}$ values from the Samara Valley to those from the Caspian. This finding is important in that it begins to address the local and regional variability that must have been present in both Neolithic and Bronze Age subsistence economies. During initial isotopic research on the steppes, it was concluded that "there appears to be little change in human diet from the Mesolithic period to the Iron Age” (O’Connell et al. 2003:261). This view has changed substantially in more recent years, further reinforced by the results from the Samara Valley presented here. As more isotopic data become available from the Central Eurasian steppes, it is becoming increasingly clear that significant variation was present, both spatially and chronologically. Understanding this variation is the task that now presents itself.

\section{Acknowledgements}

The authors would like to thank Karen Privat for permission to cite data from her DPhil thesis. Thanks are also extended to David Anthony, Dorcas Brown and Andrzej Weber for their very helpful comments on earlier drafts of the chapter. 


\section{References}

Alexander, R. M. 2009. The Relative Merits of Foregut and Hindgut Fermentation. Journal of Zoology 231:391-401.

Ambrose, S. H. 1991. Effects of Diet, Climate and Physiology on Nitrogen Isotope Abundances in Terrestrial Foodwebs. Journal of Archaeological Sciences 18:293-317.

Ambrose, S. H., and L. Norr. 1993. Experimental Evidence for the Relationship of the Carbon Isotope Ratios of Whole Diet and Dietary Protein to Those of Bone Collagen and Carbonate. In Prehistoric Human Bone: Archaeology at the Molecular Level, edited by J. B. Lambert and G. Grupe, pp. 1-37. New York: Springer-Verlag.

Anthony, D. W., D. Brown, E. Brown, A. Goodman, A. Khokhlov, P. Kosintsev, P. Kuznetsov, O. Mochalov, E. Murphy, D. Peterson, A. Pike-Tay, L. Popova, A. Rosen, N. Russell, and A. Weisskopf. 2005. The Samara Valley Project: Late Bronze Age Economy and Ritual in the Russian Steppes. Eurasia Antiqua 11:395-417.

Anthony, D. W., and D. R. Brown. 2000. Eneolithic Horse Exploitation in the Eurasian Steppes: Diet, Ritual and Riding. Antiquity 74:75-86.

Bocherens, H., and D. Drucker. 2003. Trophic Level Isotopic Enrichments for Carbon and Nitrogen in Collagen: Case Studies from Recent and Ancient Terrestrial Ecosystems. International Journal of Osteoarchaeology 13:46-53.

Bogaard, A., T. H. E. Heaton, P. Poulton, and I. Merbach. 2007. The Impact of Manuring on Nitrogen Isotope Ratios in Cereals: Archaeological Implications for Reconstruction of Diet and Crop Management Practices. Journal of Archaeological Science 34:335-343.

Bonsall, C., R. Lennon, K. McSweeney, D. Harkness, V. Boroneant, L. Bartosiewicz, R. Payton, and J. Chapman. 1997. Mesolithic and Early Neolithic in the Iron Gates: A Palaeodietary Perspective. Journal of European Archaeology 5:50-92.

Borić, D., G. Grupe, J. Peters, and Z. Mikic. 2004. Is the Mesolithic-Neolithic Subsistence Dichotomy Real? New Stable Isotope Evidence from the Danube Gorges. Journal of European Archaeology 7:221-248.

Britton, K., G. Müldner, and M. Bell. 2008. Stable Isotope Evidence for Salt-Marsh Grazing in the Bronze Age Severn Estuary, UK: Implications for Palaeodietary Analysis at Coastal Sites. Journal of Archaeological Science 35:2111-2118.

Brown, T. A., D. E. Nelson, and J. R. Southon. 1988. Improved Collagen Extraction by Modified Longin Method. Radiocarbon 30:171-177.

Castañeda, I. S., J. P. Werne, T. C. Johnson, and T. R. Filley. 2009. Late Quaternary Vegetation 
History of Southeast Africa: The Molecular Isotope Record from Lake Malawi. Palaeogeography, Palaeoclimatology, Palaeoecology 275:100-112.

DeNiro, M. J. 1985. Post-Mortem Preservation and Alteration of In Vivo Bone Collagen Isotope Ratios in Relation to Palaeodietary Reconstruction. Nature 317:806-809.

Dufour, E., H. Bocherens, and A. Mariotti. 1999. Palaeodietary Implications of Isotopic Variability in Eurasian Lacustrine Fish. Journal of Archaeological Science 26:617-627.

Frachetti, M. D. 2008. Pastoralist Landscapes and Social Interaction in Bronze Age Eurasia. University of California Press, Berkeley.

Frachetti, M. D., R. N. Spengler, G. J. Fritz, and A. N. Mar'yashev. 2010. Earliest Direct Evidence for Broomcorn Millet and Wheat in the Central Eurasian steppe region. Antiquity 84:993-1010.

Fraser, R. A., A. Bogaard, T. H. E. Heaton, M. Charles, G. Jones, B. T. Christensen, P. Halstead, I. Merbach, P. R. Poulton, D. Sparkes, and A. K. Styring. 2011. Manuring and Stable Nitrogen Isotope Ratios in Cereals and Pulses: Towards a New Archaeobotanical Approach to the Inference of Land Use and Dietary Practices. Journal of Archaeological Science 38(10):27902804.

Fry, B. 1991. Stable Isotope Diagrams of Freshwater Food Webs. Ecology 72:2293-2297.

Gaiduchenko, L. L. 2002. Organic Remains from Fortified Settlements and Necropoli of the 'Country of Towns'. In Regional Specifics in Light of Global Models BC Complex Societies of Central Eurasia from the 3rd to the 1st Millennium. Volume 2: the Iron Age; Archaeoecology, Geoarchaeology, and Palaeogeography; Beyond Central Eurasia, edited by K. Jones-Bley and D. G. Zdanovich, pp. 400-418. Washington, D.C.: Institute of Man.

Gröcke, D. R., H. Bocherens, and A. Mariotti. 1997. Annual Rainfall and Nitrogen-Isotope Correlation in Macropod Collagen: Application as a Palaeoprecipitation Indicator. Earth and Planetary Science Letters 153:279-286.

Heaton, T. H. E. 1987. The ${ }^{15} \mathrm{~N} /{ }^{14} \mathrm{~N}$ Ratios of Plants in South Africa and Namibia: Relationship to Climate and Coastal/Saline Environments. Oecologia 74:236-246.

Heaton, T. H. E., J. C. Vogel, G. von la Chevallerie, and G. Collett. 1986. Climatic Influence on the Isotopic Composition of Bone Nitrogen. Nature 322:822-823.

Hedges, R. E. M., and L. M. Reynard. 2007. Nitrogen Isotopes and the Trophic Level of Humans in Archaeology. Journal of Archaeological Science 34:1240-1251.

Higham, T. F. G., R. Warren, A. Belinskij, H. Härke, and R. Wood. 2010. Radiocarbon Dating, Stable Isotope Analysis and Diet-Derived Offsets in Ages from the Klin Yar Site, Russian North Caucasus. Radiocarbon 52:653-670. 
Hollund, H. I., T. Higham, A. Belinskij, and S. Korenevskij. 2010. Investigation of Palaeodiet in the North Caucasus (South Russia) Bronze Age Using Stable Isotope Analysis and AMS Dating of Human and Animal Bones. Journal of Archaeological Science 37:2971-2983.

Hunt, H. V., M. Vander Linden, X. Liu, G. Motuzaite-Matuzeicuite, S. Colledge, and M. K. Jones. 2008. Millets across Eurasia: Chronology and Context of Early Records of the Genera Panicum and Setaria from Archaeological Sites in the Old World. Vegetation History and Archaeobotany 17:5-18.

Iacumin, P., V. Nikolaev, L. Genoni, M. Ramigni, Y. G. Ryskov, and A. Longinelli. 2004. Stable Isotope Analyses of Mammal Skeletal Remains of Holocene Age from European Russia: A Way to Trace Dietary and Environmental Change. Geobios 37:37-47.

Jim, S., V. Jones, S. H. Ambrose, and R. P. Evershed. 2006. Quantifying Dietary Macronutrient Sources of Carbon for Bone Collagen Biosynthesis Using Natural Abundance Stable Carbon Isotope Analysis. British Journal of Nutrition 95:1055-1062.

Karamanos, R. E., R. P. Voroney, and D. A. Rennie. 1981. Variation Natural $\mathrm{N}^{15}$ Abundance of Central Saskatchewan Soils. Soil Science of American Journal 45:826-828.

Katzenberg, M. A., V. I. Bazaliiskii, O. I. Goriunova, N. Savel'ev, and A. W. Weber. 2010. Diet Reconstruction of Prehistoric Hunter-Gatherers in the Lake Baikal Region. In Prehistoric Hunter-Gatherers of the Baikal Region, Siberia, edited by A. W. Weber, M. A. Katzenberg, and T. G. Schurr, pp. 175-191. Philadelphia: University of Pennsylvania Press.

Katzenberg, M. A., O. I. Goriunova, and A. Weber. 2009. Paleodiet Reconstruction of Early Bronze Age Siberians from the Site of Khuzhir-Nuge XIV, Lake Baikal. Journal of Archaeological Science 36:663-674.

Katzenberg, M. A., and A. Weber. 1999. Stable Isotope Ecology and Palaeodiet in the Lake Baikal Region of Siberia. Journal of Archaeological Science 26:651-659.

Khazanov, A. M. 1994. Nomads and the Outside World. 2nd ed. Madison: University of Wisconsin Press.

Khodorevskaya, R. P., G. J. Ruban, and D. S. Pavlov. 2009. Behaviour, Migrations, Distribution, and Stocks of Sturgeons in the Volga-Caspian Basin. World Sturgeon Conservation Society, Special Publication No. 3, Norderstedt.

Koryakova, L. N., and A. V. Epimakhov. 2006. The Urals and Western Siberian in the Bronze and Iron Ages. Cambridge: Cambridge University Press.

Kremenetski, C. V., T. Böttger, F. W. Junge, and A. G. Tarasov. 1999. Late- and Postglacial Environment of the Buzuluk Area, Middle Volga Region, Russia. Quaternary Science Reviews 18:1185-1203. 
Levine, M. 1999. The Origins of Horse Husbandry on the Eurasian Steppe. In Late Prehistoric Exploitation of the Eurasian Steppe, edited by M. Levine, Y. Rassamakin, A. Kislenko, and N. Tatarintseva, pp. 5-58. Cambridge: McDonald Institute.

Lillie, M., and K. Jacobs. 2006. Stable Isotope Analysis of 14 Individuals from the Mesolithic Cemetery of Vasilyevka II, Dnieper Rapids Region, Ukraine. Journal of Archaeological Science 33:880-886.

Lillie, M. C., and M. Richards. 2000. Stable Isotope Analysis and Dental Evidence of Diet at the Mesolithic-Neolithic Transition in Ukraine. Journal of Archaeological Science 27:965-972.

Makarewicz, C.A. 2014. Winter Pasturing Practices and Variable Fodder Provisioning Detected in Nitrogen $\left(\delta^{15} \mathrm{~N}\right)$ and Carbon $\left(\delta^{13} \mathrm{C}\right)$ Isotopes in Sheep Dentinal Collagen. Journal of Archaeological Science 41:502-510.

Morales, A., and E. Antipina. 2003. Srubnaya Faunas and Beyond: A Critical Assessment of the Archaeozoological Information from the East European Steppe. In Prehistoric Steppe Adaptation and the Horse, edited by M. A. Levine, C. Renfrew, and K. Boyle, pp. 329-351. Cambridge: McDonald Institute for Archaeological Research.

Motuzaite-Matuzeviciute, G., R. A. Staff, H.V. Hunt, X. Liu, and M. K. Jones. 2013. The Early Chronology of Broomcorn Millet (Panicum miliaceum) in Europe. Antiquity 87:1073-1085.

Murphy, E. M., R. J. Schulting, N. Beer, A. Kasparov, and M. Pshenitsyna. 2013. Iron Age Diet in Southern Siberia: Information from Stable Carbon and Nitrogen Isotopes and Dental Palaeopathology. Journal of Archaeological Science 40(5):2547-2560.

O'Connell, T. C., M. A. Levine, and R. E. M. Hedges. 2003. The Importance of Fish in the Diet of Central Eurasian Peoples from the Mesolithic to the Early Iron Age. In Prehistoric Steppe Adaptation and the Horse, edited by M. A. Levine, C. Renfrew, and K. Boyle, pp. 253-268. Cambridge: McDonald Institute for Archaeological Research.

Otroshchenko, V. V. 2003. The Economic Peculiarities of the Srubnaya Cultural-Historical Entity. In Prehistoric Steppe Adaptation and the Horse, edited by M. A. Levine, C. Renfrew, and K. Boyle, pp. 319-328. Cambridge: McDonald Institute for Archaeological Research.

Outram, A. K., N. A. Stear, R. Bendrey, S. Olsen, A. Kasparov, V. Zaibert, N. Thorpe, and R. Evershed. 2009. The Earliest Horse Harnessing and Milking. Science 323:1332-1335.

Page, H. M. 1995. Variation in the Natural Abundance of ${ }^{15} \mathrm{~N}$ in the Halophyte, Silicornia virginica, Associated with Groundwater Subsidies of Nitrogen in a Southern California SaltMarsh. Oecologia 104:181-188.

Pate, F. D., and T. J. Anson. 2008. Stable Nitrogen Isotope Values in Arid-Land Kangaroos Correlated with Mean Annual Rainfall: Potential as a Palaeoclimatic Indicator. International 
Journal of Osteoarchaeology 18:317-326.

Piezonka, H., E. Kostyleva, M. G. Zhilin, D. Maria, and T. Terberger. 2013. Flesh or Fish? First Results of Archaeometric Research of Prehistoric Burials from Sakhtysh IIa, Upper Volga Region, Russia. Documenta Praehistorica 40:57-73.

Privat, K. 2004. Palaeoeconomy of the Eurasian Steppe: Biomolecular Studies. Unpublished DPhil thesis, University of Oxford, Oxford.

Privat, K., T. O'Connell, K. Neal, and R. Hedges. 2005. Fermented Dairy Product Analysis and Palaeodietary Repercussions: Is Stable Isotope Analysis Not Cheesy Enough? In The Zooarchaeology of Fats, Oils, Milk and Dairying, edited by Jacqui Mulville and Alan K. Outram, pp. 60-66. Oxford: Oxbow Books.

Pyankov, V. I., P. D. Gunin, S. Tsoog, and C. C. Black. 2000. C4 Plants in the Vegetation of Mongolia: Their Natural Occurrence and Geographical Distribution in Relation to Climate. Oecologia 123:15-31.

Richards, M. P. 2000. Human Consumption of Plant Foods in the British Neolithic: Direct Evidence from Bone Stable Isotopes. In Plants in Neolithic Britain and Beyond, edited by A. S. Fairbairn, pp. 123-135. Oxford: Oxbow.

Richards, M. P., and R. E. M. Hedges. 1999. Stable Isotope Evidence for Similarities in the Types of Marine Foods Used by Late Mesolithic Humans on the Atlantic Coast of Europe. Journal of Archaeological Science 26:717-722.

Schoeninger, M. J. 1989. Reconstructing Prehistoric Human Diet. In The Chemistry of Prehistoric Human Bone, edited by T. D. Price, pp. 38-67. Cambridge: Academic Press.

Schoeninger, M. J., and M. J. DeNiro. 1984. Nitrogen and Carbon Isotopic Composition of Bone Collagen from Marine and Terrestrial Animals. Geochimica et Cosmochimica Acta 48:625-639.

Schulting, R. J. 2011. Mesolithic-Neolithic Transitions: An Isotopic Tour through Europe. In The Bioarchaeology of the Transition to Agriculture, edited by Ron Pinhasi and Jay Stock, pp. 1744. New York: Wiley-Liss.

Schurr, M. R. 1998. Using Stable Nitrogen Isotope Ratios to Study Weaning Behavior in Past Populations. World Archaeology 30:327-342.

Schwarcz, H. P., T. L. Dupras, and S. I. Fargrieve. 1999. ${ }^{15} \mathrm{~N}$ Enrichment in the Sahara: In Search of a Global Relationship. Journal of Archaeological Science 26:651-659.

Sealy, J. C., N. J. van der Merwe, J. A. Lee Thorp, and J. L. Lanham. 1987. Nitrogen Isotopic Ecology in Southern Africa: Implications for Environmental and Dietary Tracing. Geochimica et Cosmochimica Acta 51:2707-2717. 
Séfériadès, M. 2000. In the Heart of the Eurasian Steppe: Ancient Hunter-Gatherers, First Sedentary Farmers and Nomad Stock Herders of Mongolia (8000-3000 BC). In Late Prehistoric Exploitation of the Eurasian Steppe, Vol. 2, edited by Y. Rassamakin, A. Kislenko, and N. Tatarintseva, pp. 141-159. Cambridge: McDonald Institute.

Shishlina, N. I. 2008. Reconstruction of the Bronze Age of the Caspian Steppes. Oxford: Archaeopress, BAR International Series 1876.

Shishlina, N.I. 2001. The Seasonal Cycle of Grassland Use in the Caspian Sea Steppe during the Bronze Age: A New Approach to an Old Problem. European Journal of Archaeology 4:346-366.

Shishlina, N.I., V. Sevastyanov, and R.E.M. Hedges. 2012. Isotope Ratio Study of Bronze Age Samples from the Eurasian Caspian Steppes. In Population Dynamics in Prehistory and Early History. New Approaches by Using Stable Isotopes and Genetics, edited by E. Kaiser, J. Burger and W. Schier, pp. 177-197. Berlin: De Gruyter.

Shishlina, N. I., J. Van der Plicht, R. E. M. Hedges, E. P. Zazovskaya, V. S. Sevastyanov, and O. A. Chichagova. 2007. The Catacomb Cultures of the North-West Caspian Steppe: ${ }^{14} \mathrm{C}$ Chronology, Reservoir Effect, and Paleodiet. Radiocarbon 49:713-726.

Shishlina, N. I., E. P. Zazovskaya, J. van der Plicht, R. E. M. Hedges, V. S. Sevastyanov, and O. A. Chichagova. 2009. Paleoecology, Subsistence, and ${ }^{14} \mathrm{C}$ Chronology of the Eurasian Caspian Steppe Bronze Age. Radiocarbon 51:481-499.

Svyatko, S. V. 2009. Palaeodietary Analysis of Prehistoric Populations from the Minusinsk Basin, Southern Siberia. Unpublished PhD thesis, Queen's University Belfast.

Svyatko, S. V., J. P. Mallory, E. M. Murphy, A. V. Polyakov, P. J. Reimer, and R. J. Schulting. 2009. New Radiocarbon Dates and a Review of the Chronology of Prehistoric Populations from the Minusinsk Basin, Southern Siberia, Russia. Radiocarbon 51:243-273.

Svyatko, S. V., R. J. Schulting, J. Mallory, E. M. Murphy, P. Reimer, V. I. Khartanovich, Y. K. Chistov, N. V. Leontyev, and M. V. Sablin. 2013. Stable Isotope Dietary Analysis of Bronze to Early Iron Age Populations in the Minusinsk Basin, Southern Siberia, Russia. Journal of Archaeological Science 40(11):3936-3945.

Tieszen, L. L. 1991. Natural Variations in the Carbon Isotope Values of Plants: Implications for Archaeology, Ecology, and Paleoecology. Journal of Archaeological Science 18:261-275.

Vanderklift, M. A., and S. Ponsard. 2003. Sources of Variation in Consumer-Diet $\delta 15 \mathrm{~N}$ Enrichment: A Meta-Analysis. Oecologia 136:169-182.

van der Plicht, J., N. I. Shishlina, R. E. M. Hedges, E. P. Zazovskaya, V. S. Sevastianov, and O. A. Chichagova. 2007. Reservoir Effect and Results of ${ }^{14} \mathrm{C}$ dating of Catacomb Cultures of the North-West Caspian Steppe Area: A Case Study. Rossijskaâ arheologiâ 2:39-47. 
van Groenigen, J.-W., and C. Kessel. 2002. Salinity-Induced Patterns of Natural Abundance Carbon-13 and Nitrogen-15 in Plant and Soil. Soil Science Society of America Journal 66:489498.

Ventresca Miller, A., E. Usmanova, V. Logvin, S. Kalieva, I. Shevnina, A. Logvin, A. Kolbina, A. Suslov, K. Privat, K. Haas, and M. Rosenmeier. 2014. Subsistence and Social Change in Central Eurasia: Stable Isotope Analysis of Populations Spanning the Bronze Age Transition. Journal of Archaeological Science 42:525-538.

Wang, G. H. 2003. Differences in Leaf $\delta^{13} \mathrm{C}$ among Four Dominant Species in a Secondary Succession Sere on the Loess Plateau of China. Photosynthetica 41:525-531.

Wang, R. Z. 2004. C4 Species and Their Response to Large-Scale Longitudinal Climate Variables along the Northeast China Transect (NECT). Photosynthetica 42:71-79.

Wang, R. Z. 2005. $\mathrm{C}_{3}$ and $\mathrm{C}_{4}$ Photosynthetic Pathways and Life Form Types for Native Species from Agro-Forestry Region, Northeastern China. Photosynthetica 43:535-549.

Willis, J. C. 1973. A Dictionary of the Flowering Plants and Ferns. Cambridge University Press, Cambridge.

Winter, K. 1981. C4 Plants of High Biomass in Arid Regions of Asia-Occurrence of $\mathrm{C}_{4}$ Photosynthesis in Chenopodiaceae and Polygonaceae from the Middle East and USSR. Oecologia 48:100-106.

Wood, R.E., T. F. G. Higham, A. Buzilhova, A. Surorov, J. Heinemeier, and J. Olsen. 2013. Freshwater Radiocarbon Reservoir Effects at the Burial Ground of Minino, Northwest Russia. Radiocarbon 55(1):163-177.

Zohary, D., and M. Hopf. 2000. Domestication of Plants in the Old World. 3rd ed. Oxford: Clarendon Press. 


\section{Table captions}

Table 7.1. Stable carbon and nitrogen isotope results on human bone collagen from the Samara Valley Project.

Table 7.2 Stable carbon and nitrogen isotope averages and standard deviations ( $\pm 1 \mathrm{~S} \square$ for Neolithic/Eneolithic to Late Bronze Age human samples from the Samara Valley.

Table 7.3 Mann-Whitney U-test results for stable carbon and nitrogen isotope averages and standard deviations ( \pm 1SD) assessing locational and/or period differences.

Table 7.4 Stable carbon and nitrogen isotope averages and standard deviations ( \pm 1SD) for Neolithic/Eneolithic to Middle Bronze Age fauna from Central Eurasia. Only Privat (2004) specifies that only adult animals were analysed. Sources: this study, Hollund et al. 2010, Iacumin et al. 2004; O’Connell et al. 2003; Privat 2004; Shishlina 2008; Shishlina et al. 2007, 2009.

Table 7.5 Stable carbon and nitrogen isotope averages and standard deviations ( $\pm 1 \mathrm{SD})$ for Bronze Age adolescent/adult humans from selected regions of Central Eurasia. 


\begin{tabular}{|c|c|c|c|c|c|c|c|c|c|c|c|c|c|}
\hline Sample & Sex & Age & Site name & Provenience & Culture & Period & Region & $\delta^{13} C$ & $\delta^{15} N$ & $\% C$ & $\% N$ & $C: N$ & Yield \\
\hline 44 & $\mathrm{M}$ & maturus & Lebyanzhinka IV & settlement gr 1 & Neolithic & Neolithic & Sok River & -23.0 & 12.2 & 46.4 & 16.9 & 3.2 & 4.7 \\
\hline 43 & $\mathrm{~F}$ & maturus & Chekalino IV & settlement gr 2? & Elshanka & Neolithic & Sok River & -23.1 & 12.1 & 44.9 & 16.3 & 3.2 & 5.8 \\
\hline 34 & M & adult & Murzikha II & gr. 97 sk. 'a' & Garin-Bor & 'Eneolithic' & northern forest & -23.4 & 15.1 & 45.2 & 16.6 & 3.2 & 3.6 \\
\hline 18 & M & adult & Lebyazhinka V & settlement, gr 9 & Eneolithic & Eneolithic & Sok River & -18.9 & 12.8 & 44.7 & 16.8 & 3.1 & 8.0 \\
\hline 19 & F? & juvenis & Lebyazhinka V & settlement, gr 8 & Eneolithic & Eneolithic & Sok River & -19.2 & 11.2 & 45.5 & 16.9 & 3.1 & 11.0 \\
\hline 20 & $\mathrm{~F}$ & maturus & Lebyazhinka V & $\begin{array}{l}\text { settlement gr } 12 \\
\text { (collective) }\end{array}$ & Eneolithic & Eneolithic & Sok River & -22.2 & 13.2 & 45.4 & 16.8 & 3.2 & 6.0 \\
\hline 21 & M & maturus & Lebyazhinka V & $\begin{array}{l}\text { settlement gr } 12 \\
\text { (collective) }\end{array}$ & Eneolithic & Eneolithic & Sok River & -21.9 & 13.3 & 45.4 & 16.9 & 3.1 & 8.0 \\
\hline 22 & $\mathrm{~F}$ & maturus & Lebyazhinka V & $\begin{array}{l}\text { settlement gr } 12 \\
\text { (collective) }\end{array}$ & Eneolithic & Eneolithic & Sok River & -22.0 & 13.0 & 45.1 & 16.6 & 3.2 & 6.0 \\
\hline 23 & $\mathrm{~F}$ & maturus & Lebyazhinka V & $\begin{array}{l}\text { settlement gr } 12 \\
\text { (collective) }\end{array}$ & Eneolithic & Eneolithic & Sok River & -19.4 & 10.5 & 46.6 & 16.8 & 3.2 & 8.0 \\
\hline 33 & $\mathrm{~F}$ & maturus & Khvalinsk II & gr 32 & Khvalinsk & Eneolithic & Volga River, west bank & -21.1 & 15.4 & 45.9 & 17.0 & 3.1 & 8.5 \\
\hline 35 & M & adult & Khvalinsk II & gr 12 & Khvalinsk & Eneolithic & Volga River, west bank & -20.4 & 15.2 & 45.6 & 17.2 & 3.1 & 10.0 \\
\hline 45 & M & adult & Khvalinsk II & gr 23 & Khvalinsk & Eneolithic & Volga River, west bank & -20.6 & 14.2 & 46.4 & 17.3 & 3.1 & 10.0 \\
\hline 46 & M & maturus & Khvalinsk II & gr 1 & Khvalinsk & Eneolithic & Volga River, west bank & -20.2 & 14.8 & 46.1 & 17.1 & 3.1 & 9.8 \\
\hline 47 & M & maturus & Khvalinsk II & gr 17 & Khvalinsk & Eneolithic & Volga River, west bank & -22.2 & 13.8 & 46.4 & 17.2 & 3.1 & 5.4 \\
\hline 48 & M & adult & Khvalinsk II & gr 7 & Khvalinsk & Eneolithic & Volga River, west bank & -20.9 & 15.3 & 46.4 & 17.6 & 3.1 & 9.8 \\
\hline 3 & M & maturus & Ekaterinovka & Ex. Unit 1, gr 1 & Yamnaya & EBA & southern steppe & -19.6 & 10.0 & 41.4 & 14.5 & 3.3 & 14.4 \\
\hline 38 & M & maturus & Lopatino I & $\begin{array}{l}\text { K.30, gr } 1 \text { (was } \\
\text { K.31, gr } 1 \text { ) }\end{array}$ & $\begin{array}{l}\text { Yamnaya- } \\
\text { Repin }\end{array}$ & EBA & Sok River & -18.5 & 12.5 & 45.4 & 17.1 & 3.1 & 11.1 \\
\hline 54 & $\mathrm{~F}$ & maturus & $\begin{array}{l}\text { Kurmanaevskii } \\
\text { III }\end{array}$ & K.3, gr 1 & Yamnaya & EBA & Buzuluk River & -18.4 & 12.5 & 45.5 & 16.8 & 3.2 & 7.2 \\
\hline 5,37 & $\mathrm{~F}$ & adult & Lopatino I & K.35, gr 1 & Yamnaya & EBA & Sok River & -18.9 & 11.4 & 44.2 & 16.3 & 3.2 & 13.9 \\
\hline 52 & M & adult & Lopatino I & K.1, gr 1 & Yamnaya & EBA & Sok River & -19.7 & 11.6 & 46.4 & 17.5 & 3.1 & 14.8 \\
\hline 57 & M & juvenis & Lopatino II & K.3, gr 1 & Yamnaya & EBA & Sok River & -19.0 & 11.0 & 44.5 & 15.6 & 3.3 & 8.3 \\
\hline 58 & M & juvenis & Kutuluk I & $\begin{array}{l}\text { K.4, gr } 1 \text { (was } \\
\text { K.3, gr 1) }\end{array}$ & Yamnaya & EBA & Kutuluk River & -18.8 & 10.8 & 44.9 & 15.6 & 3.4 & 8.4 \\
\hline 50 & M & adult & Luzhki I & $\begin{array}{l}\text { flat grave } 5 \\
\text { (bound) }\end{array}$ & Potapovka? & EBA & Sok River & -19.8 & 10.2 & 45.4 & 16.9 & 3.1 & 13.2 \\
\hline 49 & $\mathrm{~F}$ & adult & Potapovka I & K.3, burial 1 & Potapovka? & MBA & Sok River & -19.2 & 11.8 & 47.0 & 17.5 & 3.1 & 9.2 \\
\hline 15 & M & maturus & Nur & single $\mathrm{K}$, gr 5 & Poltavka & MBA & Samara River & -19.0 & 11.2 & 45.7 & 17.1 & 3.1 & 12.0 \\
\hline 4 & $\mathrm{~F}$ & adult & Gvardetsi & K.1, gr 2 & Poltavka & MBA & Samara River & -18.6 & 13.2 & 42.3 & 14.6 & 3.4 & 6.2 \\
\hline 14 & $\mathrm{~F}$ & adult & Nur & single K, gr 4 & Poltavka & MBA & Samara River & -18.4 & 13.5 & 45.3 & 17.1 & 3.1 & 13.0 \\
\hline 11 & M & adult & Grachiovka II & K.1, gr 1 & Poltavka & MBA & Sok River? & -19.0 & 11.1 & 45.0 & 17.0 & 3.1 & 16.0 \\
\hline 16 & M & maturus & Nikolaevka III & K.5, gr 1 & Poltavka & MBA & Samara River & -19.3 & 10.9 & 46.9 & 17.5 & 3.1 & 12.0 \\
\hline
\end{tabular}




\begin{tabular}{|c|c|c|c|c|c|c|c|c|c|c|c|c|c|}
\hline 17 & M & maturus & Nikolaevka III & K.1, gr 3 & Poltavka & MBA & Samara River & -18.9 & 11.8 & 45.1 & 16.7 & 3.2 & 5.0 \\
\hline 42 & M & adult & Potapovka & D. 5 gr 3 & Poltavka & MBA & Sok River & -18.1 & 11.9 & 46.2 & 17.3 & 3.1 & 12.9 \\
\hline 53 & M & adult & Lopatino II & K.1, gr 1 & Poltavka & MBA & Sok River & -19.3 & 11.2 & 46.7 & 17.8 & 3.1 & 13.5 \\
\hline 51 & M & adult & Kutuluk III & K.1, gr 1 & Potapovka & MBA & Kutuluk River & -19.4 & 11.3 & 46.8 & 17.4 & 3.1 & 14.8 \\
\hline 55 & M & adult & Zhuravlikha I & K.1, gr 4 & Poltavka & MBA & Kinel River & -18.5 & 14.6 & 46.8 & 17.4 & 3.1 & 8.3 \\
\hline 24 & $\mathrm{~F}$ & adult & Utyovka IV & K.4, gr 1 & Potapovka & Late MBA & Volga River, west bank & -19.2 & 11.0 & 44.4 & 16.3 & 3.2 & 4.0 \\
\hline 36 & $\mathrm{~F}$ & adult & Potapovka & K.V, gr II & Potapovka & Late MBA & Sok River & -20.2 & 11.2 & 44.1 & 16.4 & 3.1 & 12.3 \\
\hline 41 & M & adult & Utyovka IV & D. 6 gr 2 sk 1 & Potapovka & Late MBA & Samara River & -18.6 & 10.7 & 45.5 & 16.9 & 3.1 & 3.6 \\
\hline 27 & M & maturus & Utyovka VI & K.7, gr 1 & Potapovka & Late MBA & Sok River & -18.5 & 11.5 & 46.0 & 17.5 & 3.1 & 15.0 \\
\hline 1 & $\mathrm{~F}$ & maturus & Spiridonovka IV & K.1, gr 15 & $\begin{array}{l}\text { Early } \\
\text { Srubnaya }\end{array}$ & LBA & Samara River & -18.7 & 11.6 & 44.9 & 16.9 & 3.1 & 13.0 \\
\hline 25 & $\mathrm{~F}$ & adult & Rozhdestvenno I & K.5, gr 7 & $\begin{array}{l}\text { Early } \\
\text { Srubnaya }\end{array}$ & LBA & Volga tributary & -19.5 & 11.3 & 46.3 & 17.2 & 3.1 & 12.0 \\
\hline 28 & $\mathrm{~F}$ & maturus & Spiridonovka II & K.11, gr 7 & $\begin{array}{l}\text { Early } \\
\text { Srubnaya }\end{array}$ & LBA & Samara River & -19.1 & 11.3 & 45.8 & 17.0 & 3.1 & 15.0 \\
\hline 40 & $\mathrm{~F}$ & juvenis & Spiridonovka II & K.1 gr 2 & $\begin{array}{l}\text { Early } \\
\text { Srubnaya }\end{array}$ & LBA & Samara River & -18.4 & 13.2 & 46.2 & 17.4 & 3.1 & 13.6 \\
\hline 26 & $\mathrm{~F}$ & adult & Rozhdestvenno I & K.4, gr 4 & $\begin{array}{l}\text { Early } \\
\text { Srubnaya }\end{array}$ & LBA & Volga tributary & -19.6 & 11.1 & 45.6 & 16.8 & 3.2 & 3.0 \\
\hline 29 & $\mathrm{~F}$ & adult & Spiridonovka II & K.11, gr 12 & $\begin{array}{l}\text { Early } \\
\text { Srubnaya }\end{array}$ & LBA & Samara River & -19.3 & 11.1 & 45.1 & 15.7 & 3.4 & 4.6 \\
\hline 39 & M & adult & Spiridonovka II & K.1, gr 1 & $\begin{array}{l}\text { Early } \\
\text { Srubnaya }\end{array}$ & LBA & Samara River & -19.3 & 10.4 & 46.5 & 17.4 & 3.1 & 12.5 \\
\hline 6 & $\mathrm{~F}$ & adult & Spiridonovka IV & K.1, gr 2 & Srubnaya & LBA & Samara River & -18.6 & 10.8 & 41.4 & 14.8 & 3.3 & 4.3 \\
\hline 9 & M & juvenis & Spiridonovka IV & K.2, gr 5 & Srubnaya & LBA & Samara River & -18.8 & 9.8 & 41.9 & 15.0 & 3.3 & 12.2 \\
\hline 7 & $\mathrm{~F}$ & adult & Spiridonovka IV & K.1, gr 6 & Srubnaya & LBA & Samara River & -19.3 & 9.6 & 38.9 & 13.9 & 3.3 & 15.0 \\
\hline 30 & $\mathrm{~F}$ & maturus & Barinovka I & K.2, gr 24 & Srubnaya & LBA & Samara River & -17.5 & 14.3 & 44.2 & 15.5 & 3.3 & 7.6 \\
\hline 8 & M & maturus & Spiridonovka IV & K.1, gr 11 & Srubnaya & LBA & Samara River & -18.8 & 9.9 & 42.9 & 15.5 & 3.2 & 9.5 \\
\hline 12 & M & maturus & Novosiolky & K.6, gr 1 & Srubnaya & LBA & Volga, northern forest & -19.2 & 12.1 & 45.6 & 17.1 & 3.1 & 13.0 \\
\hline 13 & M & adult & Novosiolky & K.2, gr 4 & Srubnaya & LBA & Volga, northern forest & -19.7 & 11.8 & 45.0 & 16.2 & 3.2 & 6.0 \\
\hline 31 & M & maturus & Barinovka I & K.2, gr 17 & Srubnaya & LBA & Samara River & -18.9 & 11.2 & 44.8 & 16.8 & 3.1 & 13.1 \\
\hline 32 & M & adult & Uvarovka I & K.2, gr 1 & Srubnaya & LBA & Volga River, west bank & -19.1 & 10.9 & 45.3 & 16.5 & 3.2 & 2.3 \\
\hline 2 & $\mathrm{~F}$ & adult & Belogor'e I & K.4 gr 3 & Yamnaya & MBA & Volga River, west bank & -18.5 & 13.4 & 53.2 & 18.7 & 3.3 & 11.8 \\
\hline 10 & M & maturus & Ishkinovka I & K.3, gr 7 & Yamnaya & EBA & steppe & -18.3 & 10.9 & 41.2 & 15.3 & 3.1 & 14.1 \\
\hline 60 & $\mathrm{~F}$ & adult & Tanabergin II & K.7, gr 23 & Sintashta? & MBA & Khazakhstan & -18.7 & 12.0 & 42.1 & 13.3 & 3.7 & 0.1 \\
\hline 56 & M & juvenis & Nedezhdinka & $\begin{array}{l}\text { K.1, gr } 1 \text { (was } \\
\text { K.1, gr } 6 \text { ) }\end{array}$ & Iron Age & Iron Age & Irgiz River & -18.0 & 13.2 & 45.5 & 17.1 & 3.1 & 13.9 \\
\hline 59 & $\mathrm{~F}$ & horse & Potapovka I & K. 3, gr 1 & Potapovka & Late MBA & Sok River & -20.6 & 3.8 & 44.7 & 15.6 & 3.4 & 3.4 \\
\hline
\end{tabular}


